\title{
Структурні зміни внутрішніх органів на фоні змодельованого гострого поширеного перитоніту
}

\begin{abstract}
Мета роботи: вивчення морфологічних та гістохімічних змін внутрішніх органів у піддослідних тварин на третю добу змодельованого експериментального гострого поширеного перитоніту.

Матеріали і методи. В експерименті було використано статевозрілі нелінійні щури-самки масою 180-220 грам. Гострий поширений перитоніт був змодельований шляхом інтраперитонеального введення 1 мл 30 \% калової суспензії на 100 г маси тіла щура. Тварин виводили з експерименту на третю добу шляхом декапітації під тіопенталовим наркозом. 3 метою подальшого проведення патоморфологічного та гістохімічного дослідження були забрані часточки печінки, очеревини, нирки та легені. Гістологічні препарати забарвлені гематоксилін-еозином. Фотодокументація зображення з гістологічних препаратів проводилась за допомогою виводу на монітор комп’ютера за допомогою мікроскопа Nicon eclipse C та цифрової відеокамери (Digital Camera SCMOS) за допомогою програмного забезпечення ToupWiew при різних збільшеннях.

Результати досліджень та їх обговорення. У легенях виявлено збільшення кровонаповнення судин дрібного калібру без проявів периваскулярного набряку. Дослідження на виявлення бактерій, яке проводили за методом Гімзи та за Грамом-Вейгертом, встановило наявність поодиноких грампозитивних бактерій переважно в просвітах судин та в стромі поряд із запальними інфільтратами, про що свідчать кольорові включення. Гістологічне дослідження нирок встановило незначне кровонаповнення кіркової і мозкової речовини. Гістологічне дослідження печінки на третю добу експериментального перитоніту встановило значне розширення та повнокрів’я центральних вен, із компресією центролобулярних гепатоцитів, достатньо помірне розширення синусоїдів із незначною кількістю еритроцитів та макрофагів їх у просвітах. Реакція очеревини на третю добу після моделювання розлитого перитоніту проявлялася наростанням запальної гіперемії, набряку, який поширювався на м’язову тканину.

Змодельований гострий поширений перитоніт характеризувався не лише запаленням листків очеревини, а й імунною реакцією інших органів.
\end{abstract}

Ключові слова: перитоніт; гістохімічне дослідження; метод Гімзи.

Постановка проблеми і аналіз останніх досліджень та публікацій. Перитоніт як ускладнення гострої хірургічної патології $€$ широко розповсюдженим захворюванням в цілому світі і являється важливою проблемою в екстреній абдомінальній хірургії $[1,2,3]$. Гострі запальні процеси органів черевної порожнини, порушення цілісності або проникність їх стінок, проникаючі або закриті травми живота з ушкодженням внутрішніх органів і подальшою інфекційною агресією є причинами перитоніту $[4,5,6]$. Окрім мікробних перитонітів, що розвинулися внаслідок проникнення в черевну порожнину інфекції, виділяють також асептичне запалення очеревини, зумовлене дією на очеревину різних хімічних чинників (кров, сеча, жовч, панкреатичний сік) [7, 8]. Летальність при перитоніті становить 20-30\%, а при тяжких формах даний показник сягає 40-50 \% і не має достовірних джерел щодо зниження відсотку даної патології [9, 10].

Мета роботи: вивчення морфологічних та гістохімічних змін внутрішніх органів у піддослідних тварин на третю добу змодельованого експериментального гострого поширеного перитоніту.
Матеріали і методи. В експерименті було використано статевозрілі нелінійні щури-самки, масою 180-220 грам. Гострий поширений перитоніт був змоделюваний за В. А. Лазаренком та ін. шляхом інтраперитонеального введення 1 мл $30 \%$ калової суспензії на 100 г маси тіла щура [11]. Суспензію двічі профільтрували через подвійний шар марлі та ввели щурам одразу після приготування. Калову суспензію вводили до черевної порожнини шляхом пункції вентральної стінки в центрі середньої лінії живота, кінець голки спрямовували по чергово підребер'я та клубові ділянки. 3 метою уникнення ушкодження внутрішніх органів, щурів тримали вертикально, каудальним кінцем вгору.

Тварин виводили з експерименту на третю добу шляхом декапітації під тіопенталовим наркозом. Після автопсії тварин висікали часточки печінки, очеревини, нирки та легені з метою подальшого проведення патоморфологічного та гістохімічного дослідження. Фрагменти (шматочки) органів експериментальних тканин фіксували у 10 \% розчині формальдегіду, в подальшому їх зневоднювали у спиртах зростаючої концентрації, ортоксилолі, заливали у парафін і виготовляли гістологічні зрізи за загальноприйнятою методикою. Гістологічні 
препарати забарвлювали гематоксилін-еозином. Експеримент був проведений в умовах Центральної науково-дослідної лабораторії Тернопільського національного медичного університету імені I. Я. Горбачевського МОЗ України із дотриманням загальних правил і положень Європейської Конвенції із захисту хребетних тварин, які використовуються для дослідницьких та інших наукових цілей (Страсбург, 1986) [12], та Закону України “Про захист тварин від жорстокої поведінки” (2006) [13].

Для дослідження використовували тканину очеревини, кишок, печінки, нирок, селезінки, серця та легень. Фотодокументація зображення з гістологічних препаратів проводилась за допомогою виводу на монітор комп’ютера за допомогою мікроскопа Nicon eclipse C та цифрової відеокамери (Digital Camera SCMOS) за допомогою програмного забезпечення ToupWiew при різних збільшеннях [14].

Результати досліджень та їх обговорення. На третю добу після початку моделювання розлитого перитоніту в легенях було виявлено збільшення кровонаповнення судин дрібного калібру без проявів периваскулярного набряку. Міжальвеолярна строма в окремих полях зору значно потовщувалась через збільшення лімфо-гістіоцитарної інфільтрації та появи поодиноких еритроцитів, що свідчить про незначний еритродіапедез. Просвіти альвеол залишались вільними від ексудату та клітинних елементів, візуалізувались вогнищеві дистелектази (рис. 1). В бронхіолах наростала дистонія із вогнищевими спазмами стінок, місцями із десквамацією епітелію. Мали місце еритростази в судинах дрібного калібру.

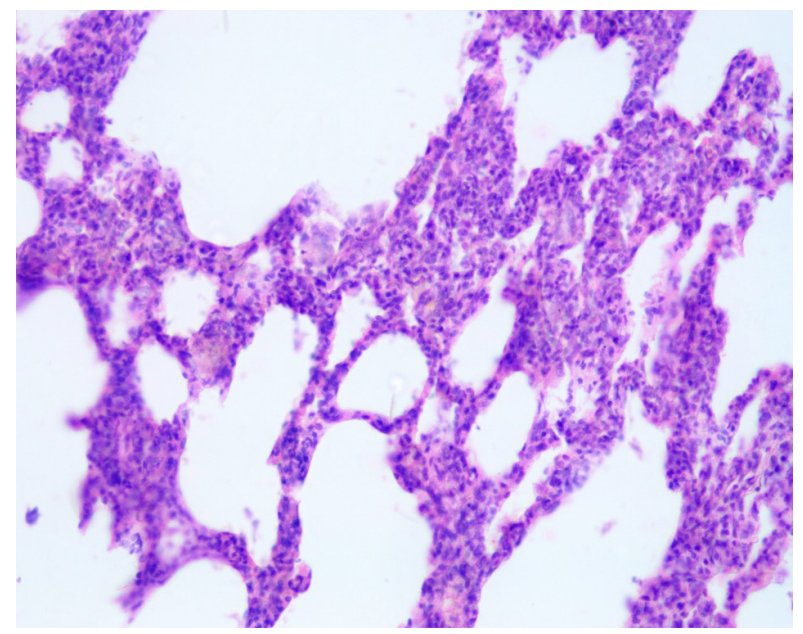

Рис. 1. Структура легені тварини при моделюванні перитоніту на третю добу експерименту. Ділянки потовщення між альвеолярною стромою. Забарвлення гематоксиліном та еозином. х 200
Гістохімічне дослідження показало дегенеративні прояви стінок судин більшого калібру, що також підтверджується зниженням або відсутністю периваскулярного набряку, тобто зменшується проникність судинної стінки. Забарвлення значної інтенсивності залишалось лише і стінках дрібних судин, що свідчило про наявність в стінках судин молодого фібрину. Тобто запальна реакція ще достатньо виражена, проте не прогресує. В стромі за висновками гістохімічного дослідження переважає зрілий фібрин, який інфільтрував тканину не більше 24 год фази ексудації (рис. 2), на що вказують помірні кольорові включення.

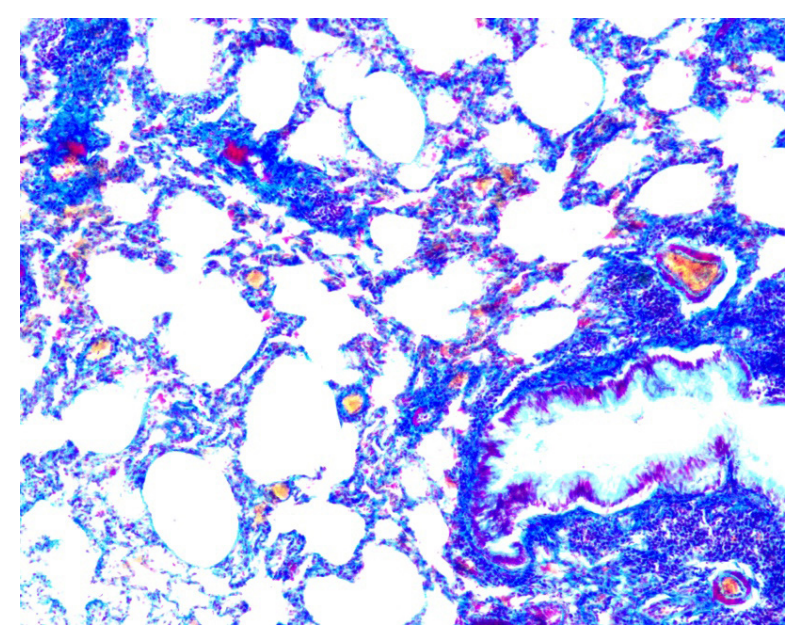

Рис. 2. Гістохімічне дослідження легені тварини при моделюванні перитоніту на третю добу експерименту. Переважання зрілого фібрину. Метод оранжевий-червоний-голубий х 100

Дослідження легень для виявлення бактерій за методом Гімзи та за Грамом-Вейгертом встановило наявність поодиноких грампозитивних бактерій переважно в просвітах судин та в стромі поряд із запальними інфільтратами, про що свідчать кольорові включення.

Гістологічне дослідження нирок встановило незначне кровонаповнення кіркової і мозкової речовини. В кірковому шарі клубочки дещо збільшувались за рахунок розширення просвіту капсул, окремі судинні клубочки зморщувались, ендотеліальні клітини артеріол ушкоджувались незначно. Епітеліоцити зовнішнього листка капсули помірно сплющувались, проте візуалізувались практично у всіх клубочках (рис. 3).

В інтерстиції просвіти судин венозного русла були помірно розширеними, місцями повнокровними. Структура більшості епітеліоцитів вивідних канальців залишалась збереженою, у мізерної 


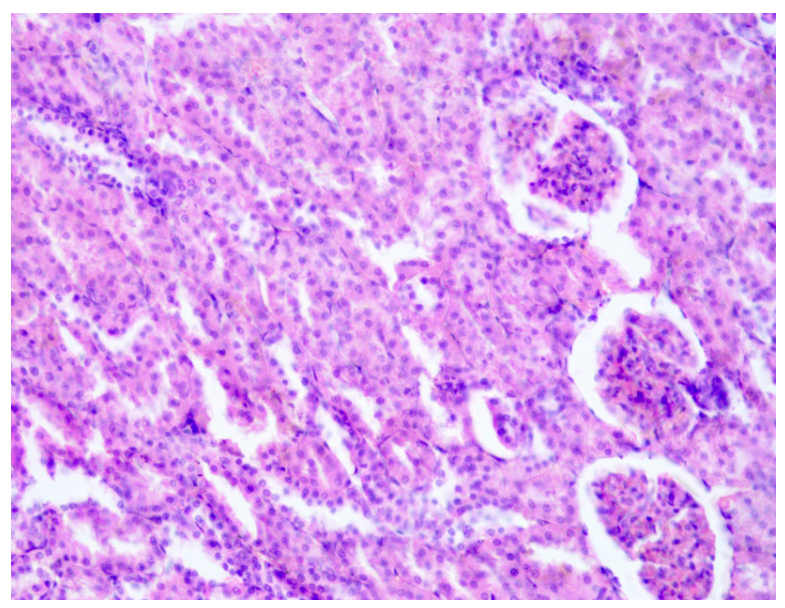

Рис. 3. Структура нирки тварини при моделюванні перитоніту на третю добу експерименту. Значне збільшення просвітів клубочків. Забарвлення гематоксиліном та еозином. х 200

частини із них виявлялись ознаки апоптозу. Ядра візуалізувались у більшості клітин, проте їх локація була різною. Окремі ядра були гіперхромні, 3 наявністю ядерець, розташовані базально, міжклітинні контакти залишались переважно збереженими. Просвіти більшості вивідних канальців незначно розширювались, містили мінімальні включення. Базальні мембрани збережені.

Гістологічне дослідження печінки на третю добу експериментального перитоніту встановило значне розширення та повнокрів'я центральних вен, із компресією центролобулярних гепатоцитів, помірне розширення синусоїдів із незначною кількістю еритроцитів та макрофагів їх в просвітах (рис. 4).

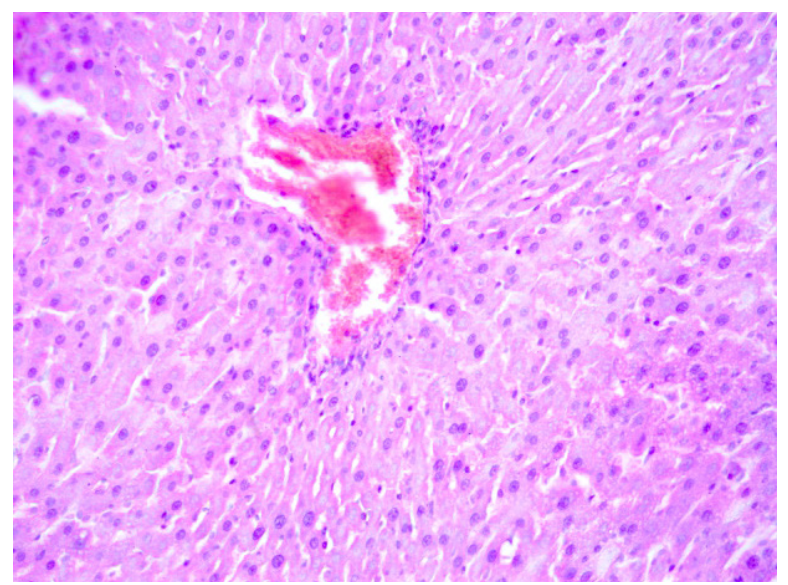

Рис. 4. Структура печінки тварини на третю добу після моделювання розлитого перитоніту. Значне розширення та повнокрів'я центральних вен із компресією центролобулярних гепатоцитів. Забарвлення гематоксиліном та еозином. х 200
Балкова організація гепатоцитів залишалась частково збереженою, проте міжклітинні контакти ушкоджувались. У більшості клітин добре візуалізувались ядра, проте значна їх частина перебувала у фазі каріопікнозу.

Площа портальних трактів також помірно збільшувалась через помірну лімфо-гістіоцитану інфільтрацію та виражений периваскулярний набряк, який поширювався частково на паренхіму та супроводжувався відкладанням незначної кількості фібрину.

Гістохімічне дослідження за методом оранжевий-червоний-голубий (ОЧГ) показало появу незначної кількості фіолетових включень у просвітах синусоїдів (рис. 5) та збільшення їх у стінці центральної вени, що свідчить про відкладання переважно зрілого фібрину. Це вказує на тривалість процесу від 24 до 48 год.
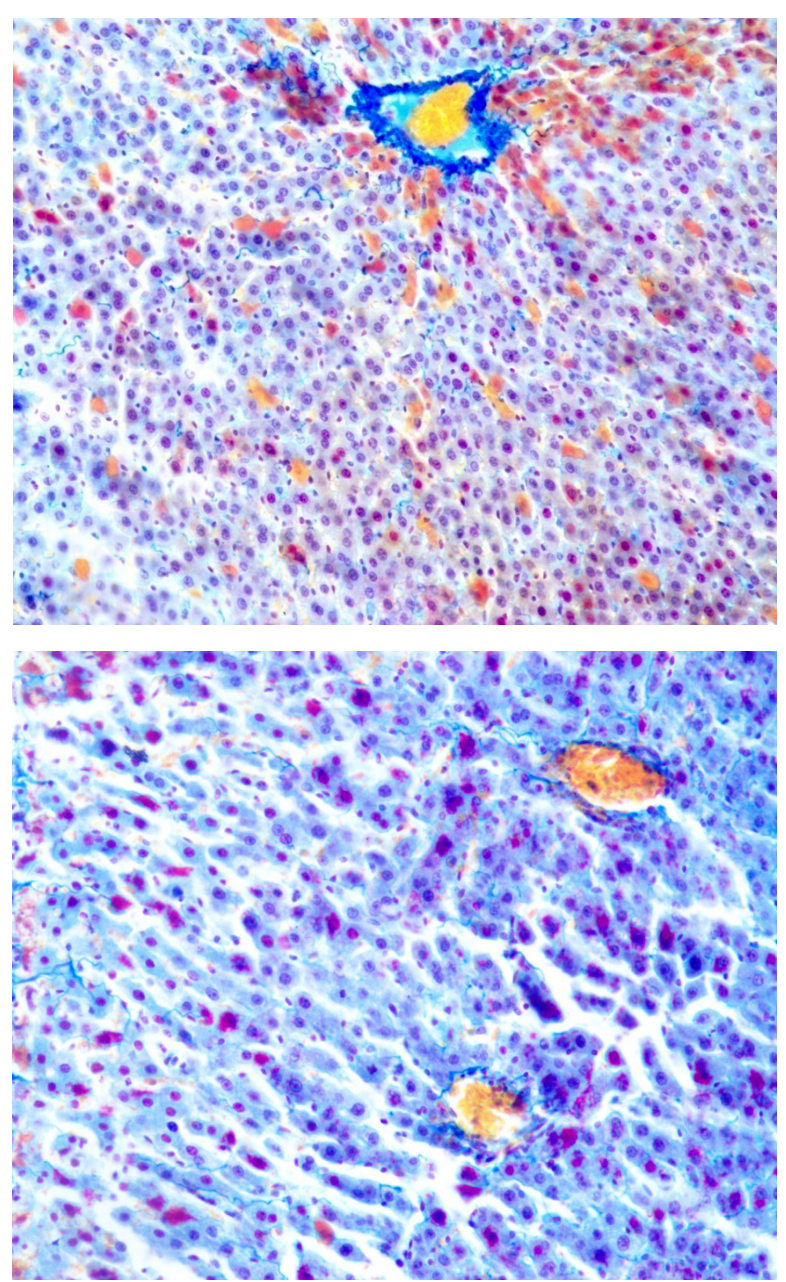

Рис. 5. Гістохімічне дослідження печінки тварини при моделюванні розлитого перитоніту на третю добу експерименту. Нашарування переважно зрілого фібрину. Метод оранжевий-червоний-голубий х 100, 200 
Гістохімічне дослідження виявило значне бактеріальне навантаження в просвітах синусоїдів та незначну кількість бактеріального компоненту в судинах портальних трактів.

Дослідження кишки встановило помірні зміни в слизовій оболонці. Візуалізувалось потовщення базальної мембрани за рахунок помірного периваскулярного набряку. Кровонаповнення судин збільшувалось, 3'являлась запальна вогнищева реакція у власній оболонці кишки у поєднанні із вогнищевою лімфо-гістіоцитарною інфільтрацією. В епітелії крипт наростала балонна білкова дистрофія, частина епітеліоцитів злущувалась у просвіт кишки; секреторна активність також зростала. В стромі виявлявся виражений набряк навколо залоз із помірною переважно плазмоцитарною інфільтрацією (рис. 6).

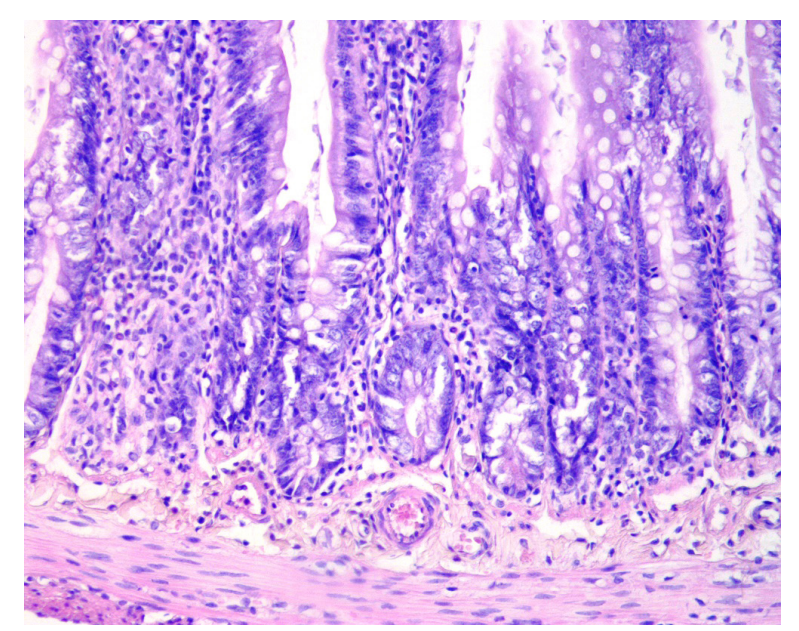

Рис. 6. Структура кишки тварини при моделюванні перитоніту на третю добу експерименту. Запальна гіперемія судин, помірний периваскулярний набряк, гідропічна дистрофія поверхневих епітеліоцитів. Забарвлення гематоксиліном та еозином. х 200

Забарвлення за методом Гімзи виявило, що виражений бактеріальний вміст переважав у запальному інфільтраті, поряд із тим спостерігався субепітеліально, переваскулярно переважно в ділянках основи крипт та базальних мембранах.

Гістохімічне дослідження методом ОЧГ виявило значну кількість фіолетових волокон як у просвіті крипт кишки, у просвіті кишки на поверхневому епітелії та в ділянці базальних мембран (рис. 7). Такі структурні прояви свідчать, що найінтенсивніша фаза запалення проявлялась протягом 24-48 год, і серед усіх досліджуваних органів найбільш інтенсивно проявлялась у слизовій оболонці кишки.

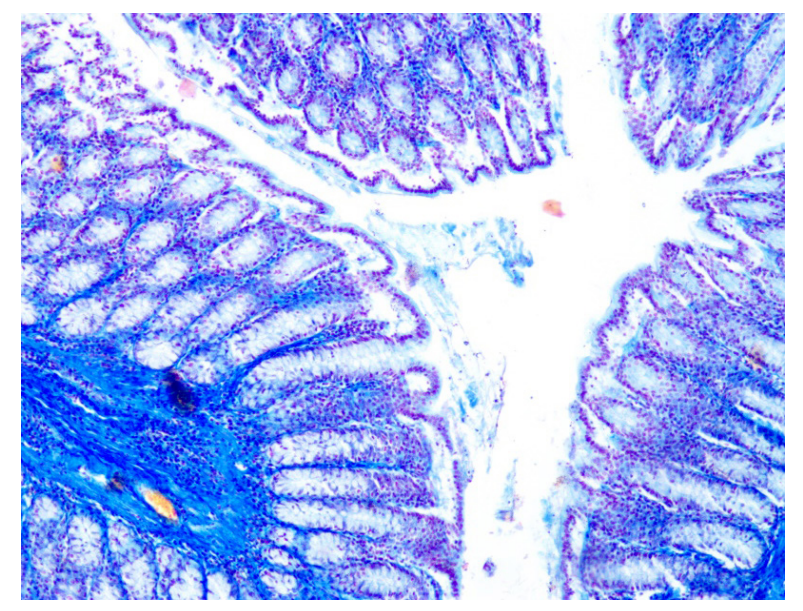

Рис. 7. Гістохімічне дослідження кишки тварини при моделюванні перитоніту на третю добу експерименту. Виражені прояви нашарування зрілого фібрину. Метод оранжевий-червоний-голубий х 200

Реакція очеревини на третю добу після моделювання розлитого перитоніту проявлялася наростанням запальної гіперемії, набряку, який поширювався на м'язову тканину (рис. 8). Значна частина мезотеліоцитів мали прояви гідропічної білкової дистрофії, інша частина перебували у фазі апоптозу.

Гістохімічне дослідження структурних елементів очеревини за методом оранжевий-червоний-голубий виявило значну кількість зрілого фібрину серед запального інфільтрату (рис. 9).

Гістохімічне дослідження за методом Гімзи встановило виражене бактеріальне навантаження в запальному інфільтраті, що підтверджується характерним забарвленням (рис. 10).

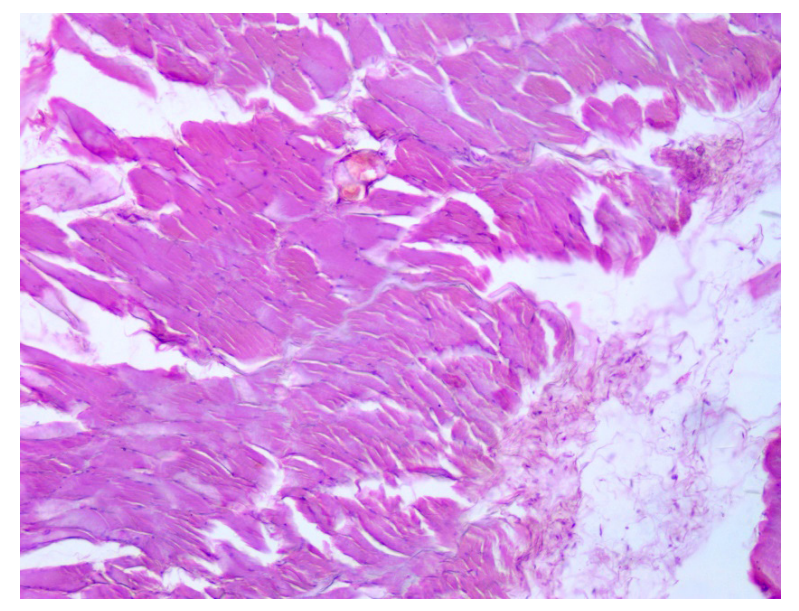

Рис. 8. Структура очеревини тварини при моделюванні розлитого перитоніту на третю добу експерименту. Наростання набряку очеревини із поширенням його на м’язову тканину. Забарвлення гематоксиліном та еозином. х 200 


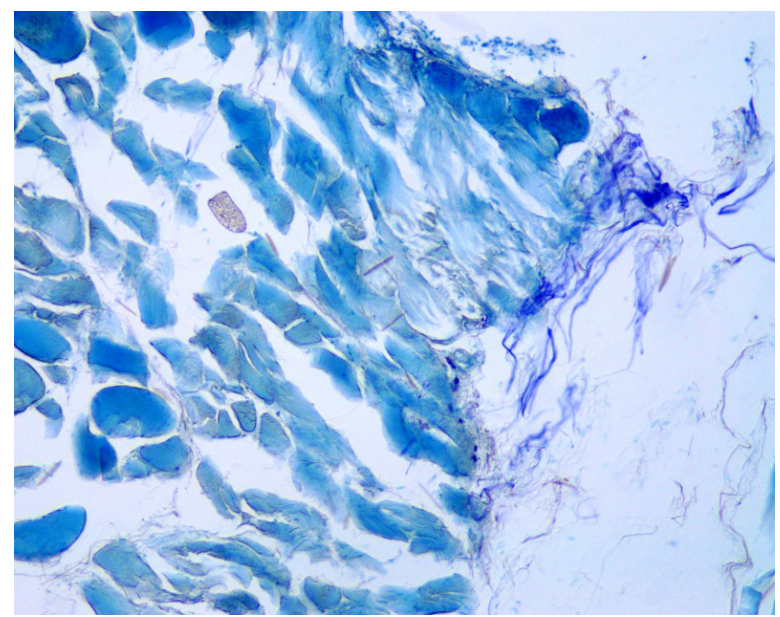

Рис. 9. Гістохімічне дослідження очеревини тварини на третю добу після моделювання розлитого перитоніту. Нашарування зрілого фібрину серед запального інфільтрату. Забарвлення за методом оранжевий-червоний-голубий. х 200

Висновки. За результатами оцінки нашого дослідження було встановлено, що змодельований гострий поширений перитоніт характеризувався не лише запаленням листків очеревини, а й імунною реакцією інших органів. У легенях було виявлено збільшення кровонаповнення судин дрібного калібру без проявів периваскулярного набряку. Дослідження для виявлення бактерій, яке проводили за методом Гімзи та за Грамом - Вейгертом, встановило наявність поодиноких грампозитивних бактерій переважно в просвітах судин та в стромі поряд із запальними інфільтратами, про що свідчать кольорові включення. Гістологічне дослідження нирок встановило незначне кровонаповнення кіркової і мозкової речовини. Гістологічне дослідження пе-

\section{СПИСОК ЛІТЕРАТУРИ}

1. Secondary peritonitis: principles of diagnosis and intervention / J. T. Ross, M. A. Matthay, H. W. Harris // BMJ (Clinical research ed.). - 2018. - Vol. 361. - P. k1407. - Access mode : https://doi.org/10.1136/bmj.k1407

2. Predictors of 30-day in-hospital mortality in patients undergoing urgent abdominal surgery due to acute peritonitis complicated with sepsis / A. Mačiulienè, A. Maleckas, A. Kriščiukaitis [et al.] // Medical Science Monitor: International Medical Journal of Experimental and Clinical Research. - 2019. - Vol. 25. - P. 6331-6340. - Access mode : https://doi.org/10.12659/ MSM.915435

3. Characterization of fecal peritonitis-induced sepsis in a porcine model / I. Park, J. H. Lee, D. H. Jang [et al.] // The Journal of Surgical Research. - 2019. - Vol. 244. - P. 492-501. Retrieved from: https://doi.org/10.1016/j.jss.2019.06.094

4. Schreyer A. G. Inflammatory and infectious abdominal peri-

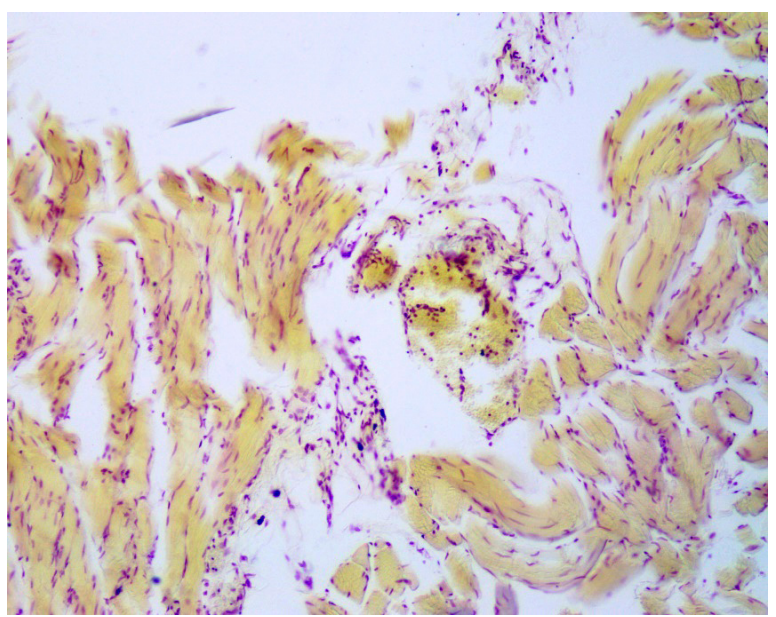

Рис. 10. Гістохімічне дослідження очеревини тварини на третю добу після моделювання локального перитоніту. Виражене бактеріальне навантаження серед запального інфільтрату. Забарвлення за методом Гімзи. x 200

чінки на третю добу експериментального перитоніту встановило значне розширення та повнокрів'я центральних вен, із компресією центролобулярних гепатоцитів, достатньо помірне розширення синусоїдів із незначною кількістю еритроцитів та макрофагів їх у просвітах. Реакція очеревини на третю добу після моделювання розлитого перитоніту проявлялося наростанням запальної гіперемії, набряку, який поширювався на м'язову тканину.

Таким чином, на третю добу після моделювання розлитого перитоніту в дослідних органах проявлялося запалення (переважно фібринозне), яке супроводжувалося наявністю грампозитивного збудника. Найбільше прояви запалення спостерігали в печінці, кишці та очеревині. toneal and mesenterial processes / A. G. Schreyer // Der Radiologe. - 2018. - Vol. 58 (1). - P. 10-18. Access mode : https://doi. org/10.1007/s00117-017-0334-8

5. CT findings in acute peritonitis: a pattern-based approach / A. Filippone, R. Cianci, Delli Pizzi [et al.] // Diagnostic and interventional radiology (Ankara, Turkey). - 2015. - Vol. 21 (6). - P. 435-440. Access mode : https://doi.org/10.5152/ dir.2015.15066

6. Primary and secondary prophylaxis of spontaneous bacterial peritonitis: current state of the art / A. Facciorusso, M. Antonino, E. Orsitto, R. Sacco // Expert Review of Gastroenterology \& Hepatology. - 2019. - Vol. 13 (8). - P. 751-759. - Access mode : https://doi.org/10.1080/17474124.2019.1644167

7. Volk S. W. Peritonitis / S. W. Volk // Small Animal Critical Care Medicine. - 2015. - P. 643-648. - Access mode : https://doi. org/10.1016/B978-1-4557-0306-7.00122-7 


\section{ЕКСПЕРИМЕНТАЛЬНІ ДОСЛІДЖЕННЯ}

8. Ordoñez C. A. Management of peritonitis in the critically ill patient / C. A. Ordoñez, J. C. Puyana // The Surgical Clinics of North America. - 2006. - Vol. 86 (6). - P. 1323-1349. - Access mode : https://doi.org/10.1016/j.suc.2006.09.006

9. Peritonitis in recent years: clinical findings and predictors of treatment response of 170 episodes at a single Brazilian center / L. G. Oliveira, J. Luengo, J. C. Caramori [et al.] // International Urology and Nephrology. - 2012. - Vol. 44 (5). - P. 1529-1537. Access mode : https://doi.org/10.1007/s11255-011-0107-7

10. Szeto C. C. Peritonitis rates of the past thirty years: from improvement to stagnation / C. C. Szeto // Peritoneal Dialysis International: Journal of the International Society for Peritoneal Dialysis. - 2014. - Vol. 34 (2). - P. 151-153. - Access mode : https:// doi.org/10.3747/pdi.2014.00007

\section{REFERENCES}

1. Ross, J. T., Matthay, M. A., \& Harris, H. W. (2018). Secondary peritonitis: principles of diagnosis and intervention. BMJ (Clinical research ed.), 361, k1407. Retrieved from: https://doi. org/10.1136/bmj.k1407

2. Mačiulienè, A., Maleckas, A., Kriščiukaitis, A., Mačiulis, V., Vencius, J., \& Macas, A. (2019). Predictors of 30-day in-hospital mortality in patients undergoing urgent abdominal surgery due to acute peritonitis complicated with sepsis. Medical Science Monitor: International Medical Journal of Experimental and Clinical Research, 25, 6331-6340. Retrieved from: https://doi. org/10.12659/MSM.915435

3. Park, I., Lee, J.H., Jang, D.H. (2019). Characterization of fecal peritonitis-induced sepsis in a porcine model. The Journal of Surgical Research, 244, 492-501. Retrieved from: https://doi. org/10.1016/j.jss.2019.06.094

4. Schreyer, A.G. (2018). Inflammatory and infectious abdominal peritoneal and mesenterial processes. Der Radiologe, 58 (1), 10-18. Retrieved from: https://doi.org/10.1007/s00117-017-03348

5. Filippone, A., Cianci, R., Delli Pizzi (2015). CT findings in acute peritonitis: a pattern-based approach. Diagnostic and Interventional Radiology (Ankara, Turkey), 21 (6), 435-440. Retrieved from: https://doi.org/10.5152/dir.2015.15066

6. Facciorusso, A., Antonino, M., Orsitto, E., Sacco, R. (2019). Primary and secondary prophylaxis of spontaneous bacterial peritonitis: current state of the art. Expert Review of Gastroenterology \& Hepatology, 13 (8), 751-759. Retrieved from: https://doi.org/1 $0.1080 / 17474124.2019 .1644167$

7. Volk, S.W. (2015). Peritonitis. Small Animal Critical Care Medicine, 643-648. Retrieved from: https://doi.org/10.1016/ B978-1-4557-0306-7.00122-7
11. Экспериментальная модель распространенного калового перитонита / В. А. Лазаренко, В. А. Липатов, Ю. Ю. Блинков, Д. В. Скориков // Человек и его здоровье. - 2008. - № 4. - С. 128-132.

12. European convention for the protection of vertebrate animals used for experimental and other scientific purposes. - Council of Europe. Strasbourg. - 1986. - No. 123.

13. Про захист тварин від жорстокого поводження : Закон України від 21 лютого 2006 р. № 3447-IV // Відомості Верховної Ради України. - 2006. - № 27. - С. 230.

14. Методики морфологічних досліджень: монографія / Багрій М. М. Діброва В. А., Попадинець О. Г., Грищук I. М.; за ред. М. М. Багрія, В. А. Діброви. - Вінниця : Нова книга, 2016. - 238 c.
8. Ordoñez, C.A., \& Puyana, J.C. (2006). Management of peritonitis in the critically ill patient. The Surgical Clinics of North America, 86 (6), 1323-1349. Retrieved from: https://doi. org/10.1016/j.suc.2006.09.006

9. Oliveira, L.G., Luengo, J., \& Caramori, J.C. (2012). Peritonitis in recent years: clinical findings and predictors of treatment response of 170 episodes at a single Brazilian center. International Urology and Nephrology, 44 (5), 1529-1537. Retrieved from: https://doi.org/10.1007/s11255-011-0107-7

10. Szeto, C.C. (2014). Peritonitis rates of the past thirty years: from improvement to stagnation. Peritoneal Dialysis International: Journal of the International Society for Peritoneal Dialysis, 34 (2), 151-153. Retrieved from: https://doi.org/10.3747/ pdi.2014.00007

11. Lazarenko, V.A., Lipatov, V.A., Blinkov, Yu.Yu., \& Skorikov, D.V. (2008). Eksperimentalnaya model rasprostranennogo kalovogo peritonita [Experimental model of widespread fecal peritonitis]. Chelove i ego zdorovye - Man and His Health, 4, 128-132 [in Russian].

12. (1986). European convention for the protection of vertebrate animals used for experimental and other scientific purposes. Council of Europe. Strasbourg.

13. (2006). Pro zakhyst tvaryn vid zhorstokogo povodzhennia [On protection of animals from cruel treatment]. Law of Ukraine of February 21, 2006 No. 3447-IV. Bulletin of the Verkhovna Rada of Ukraine [in Ukrainian].

14. Bagriy, M.M., Dibrova, V.A., Popadynets, O.G., \& Grishchuk, I.M. (2016). Metodyky morfolohichnykh doslidzhen: monohrafiia [Methods of morphological research: monograph]. Bagriy, M.M., Dibrova, V.A. (Eds.). Vinnytsia: Nova knyha [in Ukrainian]. 


\section{A. A. KOVALCHUK, T. V. DATSKO, I.YA. DZIUBANOVSKYI, V. H. DZHYVAK}

I. Horbachevsky Ternopil National Medical University

\section{STRUCTURAL CHANGES OF INTERNAL ORGANS AGAINST THE BACKGROUND OF SIMULATED ACUTE PERITONITIS}

The aim of the work: to determine the morphological and histochemical changes of internal organs in experimental animals on the third day of the simulated experimental acute peritonitis.

Materials and Methods. Mature nonlinear female rats weighing 180-220 grams were used in the experiment. Acute widespread peritonitis was modeled by intraperitoneal administration of $30 \%$ fecal suspension in an amount of 1 ml per 100 g of body weight. Animals were withdrawn from the experiment on the third day by decapitation under thiopental anesthesia. Liver, peritoneum, kidney and lung lobes were removed for further pathomorphological and histochemical study. Histological preparations are stained with hematoxylin-eosin. For photo documentation, images from histological specimens were displayed on a computer monitor using a Nicon eclipse C microscope and a Digital Camera SCMOS using ToupWiew software at various magnifications.

Results and Discussion. An increase in blood supply to small vessels without perivascular edema was detected in the lungs. Giemsa and Gram-Weigert bacterial test revealed the presence of single gram-positive bacteria, mainly in the lumen of blood vessels and in the stroma, along with inflammatory infiltrates, as evidenced by color inclusions. Histological examination of the kidneys revealed a slight blood supply to the cortical and cerebral matter. Histological examination of the liver on the third day of experimental peritonitis revealed significant dilation and plethora of central veins, with compression of centrilobular hepatocytes, rather moderate dilation of sinusoids with a small number of erythrocytes and macrophages in their lumens. The reaction of the peritoneum on the third day after the simulation of diffuse peritonitis showed an increase in inflammatory hyperemia, edema, which spread to muscle tissue.

After evaluating the results of our study, it was found that the simulated acute peritonitis was characterized not only by inflammation of the peritoneal leaves, but also by the immune response of other organs.

Key words: peritonitis; histochemical examination; Giemsa method. 